UDC 330.322:658

JEL Classification: C22, 031, 055

DOI: 10.15587/2312-8372.2020.200995

\section{Bugrov 0., Bugrova 0.}

\title{
CONTROL PROCESS DEVELOPMENT ON THE GROUND OF PROJECT VALUE DYNAMICS LAWS
}

Об’єктом дослідження є конщептуальний підхід до процесу контролю динаміки фінансово-економічної цінності будівельного проекту, досягнутої завдяки проведеному інжинірингу. Прискорення науково-технічного прогресу підкреслює перспективність цієї теми. Встановлено, що теорія динаміки цінності проекту грунтується на трьох законах. Перший закон динаміки цінності проекту наголошує, що якісне, динамічне зростання цінності відбувається лише завдяки інноваціям (раціоналізацї, креативу), а решта проектних змін має статичний характер. Графіки ізо-цінності демонструють потенційні стани фінансово-економічної иінності проекту у чотирьохвимірному просторі «час-вигоди-витрати-ризики». Кожна наступна лінія ізо-цінності, яка проходить далі від початку координат, відображає більш високий рівень інтенсивної цінності проекту. Другий закон динаміки цінності вказує, що ентропія внаслідок виконання проекту поступово знижується. Таким чином, чим раніше відбуваються інжинірингові сесії (в межах життєвого циклу проекту) для запровадження інновацій, тим вищим є потенціал впливу на динаміку цінності проекту. Третій закон динаміки цінності проекту передбачає, що абсолютний максимум цінності не може бути досягнутий. Отже, інновації, на відміну від інших факторів фінансово-економічного зростання, є невичерпним джерелом підвищення цінності проектів. Єдиним фінансово-економічним показником, який адекватно відображає динаміку иінності проекту, є коефічієнт «вигоди-витрати» («benefit-cost» ratio - BCR). Цей показник чітко враховує всі чотири фактори (виміри) ефективності проекту та фіксує саме динамічні, якісні зміни цінності. ВCR дуже схожий на визначення цінності, яке застосовується у функціонально-вартісному та ієрархічному аналізі. Це сприяє взаєморозумінню та конвергенцї у комунікаціях між зацікавленими сторонами проекту (в комплексній моделі «Кристалу» управління цінністю). Процес контролю динаміки цінності проекту спрямовує роботу команди з інжинірингу цінності на досягнення таких фінансово-економічних результатів по інвестиційно-будівельному проекту, які найкращим чином відповідають інтересам інвесторів за умови бережливого ставлення до природи та піклування про наступні покоління.

Ключові слова: ијнність проекту, коефіцієнт «вигоди-витрати», рух грошових коштів, динаміка цінності, ізо-иінності.

Received date: 27.01 .2020

Accepted date: 02.03 .2020

Published date: 30.04 .2020
Copyright (C) 2020, Bugrov O., Bugrova O. This is an open access article under the CC BY license (http://creativecommons.org/licenses/by/4.0)

\section{Introduction}

Innovation is associated with the introduction of new ideas that provide quality value growth. So, innovations are a source of dynamic, intensive formation of added value. It is innovation (rationalization, invention, etc.) that is the means to achieve the goal of the work of engineering teams of project value. At the same time, value can be created, increased also statically, extensively - without introducing innovations, but by increasing the scale of the project and the corresponding attraction or use of labour, material and financial resources to a greater extent. In the era of environmental challenges, the extensive path is an obvious potential threat, but the factor of innovative development is of particular importance.

Different subject areas (for example, physics, finance, engineering, economics and project management), each of which at first glance is peculiar, have similar principles in their foundation. From this follows the idea of bor- rowing the key principles of thermodynamics to formulate the laws of the theory of value dynamics. These laws can serve as the basis for the reasonable formation of relevant business processes. The process of monitoring the dynamics of the project value is aimed at directing the work of the engineering team to achieve such results that best meet the interests of investors, provided that they take care of environment.

The modern world is characterized by a significant acceleration of scientific and technological progress - the frequency of the emergence of new ideas and inventions is becoming increasingly high. As a result, a number of innovative opportunities arise during the implementation of the investment construction project. At the same time, it is usually possible to take advantage of such opportunities only with the informed consent of investors. So, the problem of creating a sound conceptual procedure for monitoring the dynamics of the value of a project has acquired particular relevance today. 


\section{The object of research and its technological audit}

The object of research is a conceptual approach to the process of controlling the dynamics of the financial and economic efficiency of a construction project as a result of engineering has been developed. The existing control tool, namely, the earned value management (EVM) method, allows project manager to track how the dynamics of the physical volume of works is compared with the dynamics of the expenditure of the budget for construction costs, and based on this make appropriate forecasts. The traditional EVM does not extend the analysis to the period after the commissioning of the construction project. The task is to evaluate how the decisions taken will affect the effectiveness of the entire project lifecycle. The assessment should be based on a familiar indicator for investors and take into account the time value of money.

\section{The aim and objectives of research}

The aim of research is development of the principles of the process of controlling the project value dynamics, which harmoniously meets the interests of investors and society, taking into account the best practices of value engineering.

To achieve the aim, the following objectives are set:

1. Determine the laws of the dynamics of the project value.

2. Choose an evaluation criterion that best reflects the project value dynamics.

3. Substantiate the graphs of isovalue and on this theoretical basis propose a procedure for monitoring the project value dynamics.

\section{Research of existing solutions of the problem}

The recent idea of creating the Earned Green Value management (EGVM) model aims to cover the entire project lifecycle [1]. But such a conceptual model is not an assessment of the effectiveness of an investment project; it does not take into account risks and the time value of money. Therefore, it is needed to look for a fundamentally different solution.

The issue of the interconnections of economic growth, technological development and climate change was in the focus of attention of the 2018 Nobel laureates [2]. This subconsciously leads to the idea that the solution to the problem of fundamentally justified control of the project value dynamics should be sought in the triangle «innovation/creative ideas - economics/finances - saving resources/protecting the environment».

Innovation is inextricably linked with the concept of value and is a source of sustainable, «green» development [3]. At the same time, the success of the project can't be evaluated only from the standpoint of the goals achieved, the benefits and costs should also be considered in comparison with the starting expectations of the obtained value by various stakeholders [4]. Functional-cost analysis considers the value as the total functional usefulness of the project (given its qualitative characteristics) per unit of cost or price paid [5]. However, this approach is more qualitative-comparative and scoring in nature than financial and economic. Thus, after the engineering session has increased the project value (in the interests of the consumer and from the standpoint of the value methodology [6] (SAVE International, 2007), it is advisable to monitor how these changes dynamically affect the financial and economic efficiency of the project. But there is still no conceptually substantiated process of such control research has gone along this important issue.

The issue of «statics» and «dynamics» in project management are considered as the basis for modeling direct and feedback relationships to adequately respond to the success or failure of decisions [7]. However, as expressly indicated in this work, the definition of these two concepts is conditional, the border between them is left fuzzy. The reason for this, in the appropriate context, may be a gap in basic research and the resulting difficulty in formalizing the control of successfulness of changes on the part of certain centers of influence (project stakeholders).

Relevant scientific topics have long-term roots. Many years ago, one more thing was added to the «traditional» value creation factors - innovation [8, 9]. However, despite the undoubted key importance of this factor in modern conditions, this approach has not been recognized as a systematic scientific doctrine [10]. This to some extent explains why, in the field of project management, the innovation factor, as a source of dynamic development, is still poorly understood.

Innovations are associated with the phases of the economic cycle and may have a different focus. As noted in [11], product innovation prevails during periods of economic boom, and during times of economic crisis organizational innovation and rationalization of processes are more common. In addition, there are two more types of innovation: in the field of marketing and R\&D [12]. Here let's emphasize that regardless of its nature, any innovative solution should be justified from a financial and economic point of view. The satisfaction of the best interests of the consumer through innovative improvement of the project result should occur in unison with the investor's interest in introducing (paying for) the relevant innovations. Therefore, the solution of the problem of monitoring the project value dynamics by the investor is a necessary and important task from both theoretical and practical points of view.

An important element of control is the criterion by which the result of certain decisions or actions is evaluated. In [13], it is emphasized that behind the traditional approach of financial theory, net present value (NPV) characterizes the project value for the investor. Despite some criticism, NPV continues to be a universally applicable method [14]. There is even an opinion (although no proper reasoning has been given) that NPV, as well as the internal rate of return (IRR), are those criteria that reflect the dynamic aspect of investment [15]. However, in the financial and engineering context, the question arises: is really one of these indicators, or maybe some other, is the best criterion for monitoring the project value dynamics? The indicated moment requires special study.

Let's note that this research concerns with investment and construction projects. The work [16] considers the theoretical foundations of creating the conditions for turning construction into a green and innovative sector. It is noted that the construction of facilities often causes significant greenhouse gas emissions and the use of a significant amount of natural resources. The necessity of introducing an innovation management system, which in- 
cludes an appropriate control process, is indicated. But the mechanism for controlling the profitability of innovative solutions for investors has not been defined.

The control processes in construction projects, reviewed by work [17], cover 5 factors: safety, quality of work, costs, timetable (schedule), and risk. The issue of monitoring the effectiveness of the project remained outside the scope of this study. The indicated limitation of the areas of control can be explained by established traditions and the fact that it is extremely difficult (or even impossible) to control changes in value without a methodologically justified separation of the dynamic direction of project development from the static. This problem is still fundamentally unresolved.

Based on the foregoing, it is possible to conclude that the laws of the project value dynamics and the corresponding process for monitoring the effectiveness of the project from the perspective of the investor remain an unfilled niche of scientific research. At the same time, the key condition within the framework of the conceptual model being created should be the disposition to conserve natural resources and not cause the project to harm the environment. The study should reveal the basic content of relevant facet of the «Crystal» of value management [18]. All elements of the «Crystal» conceptual model work in synergistic interaction, while synergy manifests itself most intensively in pairs of elements. The theory of the project value dynamics forms a synergistic pair with the analysis of «benefits-costs».

\section{Methods of research}

In the course of the study, the following scientific methods were used:

- method of deduction and induction, as well as the method of setting of analogies (in the determination of the project value dynamics laws);

- method for identifying cause-effect relationships and modern methods for investment appraisal (when choosing a criterion for monitoring the dynamics of project value); - methods of comparative analysis and synthesis (in substantiating the graphs of isovalue).

\section{Research results}

6.1. Determination of the project value dynamics laws. The first law can be summarized as follows. A qualitative, intensive change in the value (effectiveness) of a project can take place only thanks to creative engineering (innovative, innovation) impact. So, in order to increase the intensity of the project value, it is necessary to transfer its integral dynamic value to a higher quality level.

A more detailed formulation of this law: at one qualitative (innovative) level, project efficiency does not increase or decrease, and changes in some factors/drivers of value are mirrored by changes in others (in the fourdimensional space «time-benefit-cost-risk»). For example, reducing costs (but without increasing the innovative level of the project) will lead to an adequate deterioration, in a certain proportion, of other value drivers - timeframe, income, or project risks. The corresponding rule applies to any of the remaining specified drivers. At the same time, the increase in project efficiency that occurs when moving from one of its qualitative level to another (due to creative engineering impact) consists of a corresponding reduction in costs and/or risks, and/or an increase in benefits, and/or improvement, rationalization of time project parameters.

The second project value dynamics law is as follows. During the preparation and implementation of the project, as a result of decision-making and execution of works, the passed (delivered) parts of the amount of project costs and benefits increase step by step. At the same time, those amounts that remain forecast (estimated), as well as entropy (unstructured, unsettled, uncertainty), are gradually decreasing. As a result of this, the ability to influence the project value at its beginning is high, and in the process of performing works, the potential for the dynamics of value decreases accordingly Pausing of a project for a while increases entropy.

The third value dynamics law, based on the ideas of thermodynamics, can be formulated as follows: absolute value in the framework (lifetime) of the project can't be achieved. Soon after the next improvement of the project, new innovations will appear, and therefore, additional potential will arise for the dynamic growth of value.

6.2. The choice of indicator for monitoring the project value dynamics by the investor. Each session of the functional-cost analysis/engineering of the construction object is aimed at maximizing the project value. The methodology (standard) of value engineering interprets value as the ratio of the functional utility of the project for the consumer to the resources used to implement the project (SAVE International, 2007). Therefore, the specified standard determines the value in a way that has certain differences from the indicators of the project evaluation by the investor during the analysis of «benefits-costs».

Investors use the following modern indicators to assess the effectiveness of projects:

- net present value (NPV);

- internal rate of return (IRR);

- modified internal rate of return (MIRR);

- profitability index (PI), which is also called the

«benefit-costs ratio» (BCR);

- discounting payback (DPB)

Each indicator has features, affects the appropriateness of its use as a criterion for the investor to control the dynamics of the project value. The rationale for choosing the most appropriate (in the context of the influence of engineering on efficiency) criterion requires profiling the principles of calculating each of the alternative indicators and illustrating their properties in the framework of the example. The input data of this case reflect the initial forecast of cash flows for the construction plant project (Table 1). To provide more concise information, in this and all following tables rows $4-7$ are left intentionally missed.

Modern methods for evaluating the effectiveness of projects take into account the value of money over time. Discount factors $\left(k_{n}\right)$ are calculated based on the interest rate.

The risk-designed (risk-adjusted) interest rate ( $i$ ) may take into account fluctuations in the riskiness of the project associated with changes in project parameters (benefits, costs, time frames). For example, if a decision is made about the late start of a number of works in accordance with the timetable, this will increase the risk that the construction object will not be put into operation on time. 
So, the risk of delaying the start date of receiving benefits for the project will increase. Thus, in this case, the interest rate for calculating the discount coefficients of the cash flow of the project must be increased accordingly, as disclosed later in the text.

Table 1

Cash flow forecast reflecting the financial result of the first session of the project value engineering, thousand USD

\begin{tabular}{|c|c|c|c|c|}
\hline $\begin{array}{c}\text { Year, } \\
\Pi\end{array}$ & $\begin{array}{c}\text { Capital } \\
\text { investments }\end{array}$ & $\begin{array}{c}\text { Revenues during } \\
\text { operating activities }\end{array}$ & $\begin{array}{c}\text { Expenses during } \\
\text { operating activities }\end{array}$ & $\begin{array}{c}\text { Net cash } \\
\text { flow, } N_{n}\end{array}$ \\
\hline 0 & $-8,000$ & - & - & $-8,000$ \\
\hline 1 & $-12,000$ & - & - & $-12,000$ \\
\hline 2 & $-8,000$ & - & - & $-8,000$ \\
\hline 3 & - & 16,000 & $-9,000$ & 7,000 \\
\hline 8 & - & 16,000 & $-9,000$ & 7,000 \\
\hline 9 & - & 16,000 & $-9,000$ & 7,000 \\
\hline 10 & - & 16,000 & $-9,000$ & 7,000 \\
\hline 11 & - & 16,000 & $-9,000$ & 7,000 \\
\hline Total & $-28,000$ & 144,000 & $-81,000$ & 35,000 \\
\hline
\end{tabular}

So, based on the foregoing, the present value of cash flows for the project is calculated under conditions when the initial rate, for example, is $10 \%, 12 \%$ and $15 \%$ per annum (Table 2)

Table 2

Present value of project cash flows

\begin{tabular}{|c|c|c|c|c|c|c|}
\hline $\begin{array}{c}\text { Year, } \\
n\end{array}$ & $\begin{array}{c}k_{n} \text { in the } \\
\text { case of } \\
i=10 \%\end{array}$ & $\begin{array}{c}\text { Present } \\
\text { value of net } \\
\text { cash flows, } \\
\text { thousand } \\
\text { USD }\end{array}$ & $\begin{array}{c}k_{n} \text { in the } \\
\text { case of } \\
i=12 \%\end{array}$ & $\begin{array}{c}\text { Present } \\
\text { value of net } \\
\text { cash flows, } \\
\text { thousand } \\
\text { USD }\end{array}$ & $\begin{array}{c}k_{n} \text { in the } \\
\text { case of } \\
i=15 \%\end{array}$ & $\begin{array}{c}\text { Present } \\
\text { value of net } \\
\text { cash flows, } \\
\text { thousand } \\
\text { USD }\end{array}$ \\
\hline 0 & 1 & $-8,000.00$ & 1 & $-8,000.00$ & 1 & $-8,000.00$ \\
\hline 1 & 0.9091 & $-10,909.09$ & 0.8929 & $-10,714.29$ & 0.8696 & $-10,434.78$ \\
\hline 2 & 0.8264 & $-6,611.57$ & 0.7972 & $-6,377.55$ & 0.7561 & $-6,049.15$ \\
\hline 3 & 0.7513 & $5,259.20$ & 0.7118 & $4,982.46$ & 0.6575 & $4,602.61$ \\
\hline 8 & 0.4665 & $3,265.55$ & 0.4039 & $2,827.18$ & 0.3269 & $2,288.31$ \\
\hline 9 & 0.4241 & $2,968.68$ & 0.3606 & $2,524.27$ & 0.2843 & $1,989.84$ \\
\hline 10 & 0.3855 & $2,698.80$ & 0.3220 & $2,253.81$ & 0.2472 & $1,730.29$ \\
\hline 11 & 0.3505 & $2,453.46$ & 0.2875 & $2,012.33$ & 0.2149 & $1,504.60$ \\
\hline Total & - & $7,796.01$ & - & $4,641.70$ & - & 772.09 \\
\hline
\end{tabular}

Net present value (NPV) is calculated as the sum of present values of annual cash flows, some of which are negative and the rest are positive.

Thus, the numerical values of the NPV of the project, after the first session of engineering of value, are presented in the column «Sum» of the Table 2 (subject to three different discount rates). Obviously, NPV depends on all four value factors: income (benefits), expenses (costs), terms (temporary chronology of cash flows) and riskadapted discount rate. So, at this stage of the analysis, NPV remains among the contenders for the role of the criterion for controlling the project value dynamics.
The internal rate of return (IRR) is the interest rate at which capital grows within the project, and therefore, when applying it, the NPV of the project is zero:

$$
I R R=i \text {, for which } N P V=\sum_{n=0}^{\tau}\left(N_{n} \cdot \frac{1}{(1+i)^{n}}\right)=0 .
$$

Thus, IRR is a function of only three factors of determining value and does not depend on the fourth dimension of the project-financial space - the risk-adapted discount rate. According to the given case, the IRR of the project, based on data on net cash flows (column 5, Table 1), is $15.695 \%$. So, to control the dynamics of the project value, this indicator is not advisable: changing the risk of the project does not lead to fluctuations in IRR.

DPB shows for what period of time the discounted net benefits (cash inflows) from the project will cover the investment for its implementation:

$$
D P B=t+\frac{S_{t}}{D_{t+1}}
$$

where $t$ - the serial number of the last year, where the negative cumulative cash flow for the project is still remains; $S_{t}$ - the absolute value of cumulative discounted cash flows at the end of period $t ; D_{t+1}$ - net discounted net cash flow in the year that follows immediately after $t$.

According to the case (Table 3), if the initial rate is $10 \%$, the discounted payback period from the moment the project starts is:

$$
D P B=9+\frac{324.94}{2968.68}=9.11 \text { years. }
$$

And since the start of putting the construction project into operation, DPB is 6.11 years (because construction will last 3 years).

Table 3

Discounted cash flow for the project (in the vase of $i=10 \%$ )

\begin{tabular}{|c|c|c|c|}
\hline Year & $\begin{array}{c}\text { Serial number } \\
\text { of the year }\end{array}$ & $\begin{array}{c}\text { Present value of } \\
\text { net cash flow, } \\
\text { thousand U5D }\end{array}$ & $\begin{array}{c}\text { Present value of net cash } \\
\text { flow, cumulative total, } \\
\text { thousand U5D }\end{array}$ \\
\hline 0 & 1 & $-8,000.00$ & $-8,000.00$ \\
\hline 1 & 2 & $-10,909.09$ & $-18,909.09$ \\
\hline 2 & 3 & $-6,611.57$ & $-25,520.66$ \\
\hline 3 & 4 & $5,259.20$ & $-20,261.46$ \\
\hline 8 & $t=9$ & $3,265.55$ & -324.94 \\
\hline 9 & 10 & $2,968.68$ & $2,643.75$ \\
\hline 10 & 11 & $2,698.80$ & $5,342.55$ \\
\hline 11 & 12 & $2,453.46$ & $7,796.01$ \\
\hline
\end{tabular}

Thus, DPB takes into account all four factors of value determination. At the same time, one of them, namely the project benefits, is only partially taken into account cash flow beyond the payback period is ignored. At the end of the payback period, the net cash flow can either increase or decrease, which is not taken into account by this indicator. In addition, even a stable cash flow over the years as a result of discounting turns into a nonlinear 
function. So, DPB can't be considered a reliable criterion for monitoring the dynamics of the value of a project.

In the relevant context, the profitability index (PI), or, as it is also called, the benefits-costs ratio (BCR), is the ratio of the amount of discounted benefits to the sum of the discounted project costs:

$$
B C R=\frac{\sum_{n=0}^{\tau}\left(P_{n} \cdot k_{n}\right)}{\sum_{n=0}^{\tau}\left(C_{n} \cdot k_{n}\right)},
$$

where $P_{n}$ - cash inflows (benefits) in the period $n$; $C_{n}-$ cash outflows (expenses) in the period $n ; k_{n}$ - the discount factor that takes into account the depreciation of funds from the moment the project starts to the period (year) $n$.

Formula (4) is characterized by the fact that, in contrast to the traditional approach to calculating this indicator, it is based not on net cash flows, but on cash outflows (expenses) and inflows (benefits). Thus, this approach, in particular, takes into account the resource load of the project after putting the construction project into operation - the less such a load (for given net cash flows), the higher the BCR becomes. Therefore, this approach helps to minimize the negative impact of the project on the environment, corresponds to the principle of the «Crystal» of value management in harmony with nature.

According to the case (Table 4), if the rate, for example, is $12 \%$, the $\mathrm{BCR}$ is:

$$
B C R=\frac{67962.37}{63320.67}=1.0733 .
$$

For comparison, let's note that in the case of $i=10 \%$, the «benefit-cost» ratio for the business case is 1.1140 , and if $15 \%$, then 1.0136 .

Tahle 4

The benefits and costs of the project (in the case of $i=12 \%$ ), thousand USD

\begin{tabular}{|c|c|c|c|c|}
\hline Year & $\begin{array}{c}\text { Cash inflows } \\
\text { (benefits) }\end{array}$ & $\begin{array}{c}\text { Cash outflows } \\
\text { (expenses) }\end{array}$ & $\begin{array}{c}\text { Discounted } \\
\text { benefits }\end{array}$ & $\begin{array}{c}\text { Discounted } \\
\text { expenses }\end{array}$ \\
\hline 0 & 0 & $-8,000$ & 0.00 & $8,000.00$ \\
\hline 1 & 0 & $-12,000$ & 0.00 & $10,714.29$ \\
\hline 2 & 0 & $-8,000$ & 0.00 & $6,377.55$ \\
\hline 3 & 16,000 & $-9,000$ & $11,388.48$ & $6,406.02$ \\
\hline 8 & 16,000 & $-9,000$ & $6,462.13$ & $3,634.95$ \\
\hline 9 & 16,000 & $-9,000$ & $5,769.76$ & $3,245.49$ \\
\hline 10 & 16,000 & $-9,000$ & $5,151.57$ & $2,897.76$ \\
\hline 11 & 16,000 & $-9,000$ & $4,599.62$ & $2,587.28$ \\
\hline Total & 144,000 & $-109,000$ & $67,962.37$ & $63,320.67$ \\
\hline
\end{tabular}

The BCR indicator takes into account all four dimensions of the project performance space, through which it is acceptable for use as a criterion for monitoring the dynamics of value.

The calculation of the modified internal rate of return (MIRR) provides, first of all, the conversion (transformation) of cash flow for the project as follows. Net cash outflows (investments) are discounted, and net cash inflows, on the contrary, are compounded. The calculation of the usual IRR, as can be seen from the above, does not provide for such a procedure. Compounding ratios are calculated based on the risk-adjusted interest rate $(i)$.

According to the above example, if the initial rate is, for example, $10 \%$, then the cash flow for the project is transformed as follows. At the beginning of the project, expenses are modified in the amount of 25,520.66 thousand USD, and at the end of the compounding project, benefits will amount to 95,056.34 thousand USD (Table 5).

Table 5

Modification of cash flows for the project (in the case of $i=10 \%$ )

\begin{tabular}{|c|c|c|c|c|c|c|}
\hline $\begin{array}{c}\text { Year, } \\
n / n^{\prime}\end{array}$ & $\begin{array}{c}\text { Net cash } \\
\text { flows, } \\
\text { thousand } \\
\text { U5D }\end{array}$ & $\begin{array}{c}\text { Com- } \\
\text { pounding } \\
\text { ratios } \\
K_{n^{\prime}}\end{array}$ & $k_{n}$ & $\begin{array}{c}\text { Modified } \\
\text { benefits, } \\
\text { thousand } \\
\text { U5D }\end{array}$ & $\begin{array}{c}\text { Modified } \\
\text { expenses, } \\
\text { thousand } \\
\text { U5D }\end{array}$ & $\begin{array}{c}\text { Result, } \\
\text { thousand } \\
\text { U5D }\end{array}$ \\
\hline $0 / 11$ & $-8,000$ & - & 1 & - & $-8,000.00$ & $-25,520.66$ \\
\hline $1 / 10$ & $-12,000$ & - & 0.9091 & - & $-10,909.09$ & - \\
\hline $2 / 9$ & $-8,000$ & - & 0.8264 & - & $-6,611.57$ & - \\
\hline $3 / 8$ & 7,000 & 2.1436 & - & $15,005.12$ & - & - \\
\hline $8 / 3$ & 7,000 & 1.3310 & - & $9,317.00$ & - & - \\
\hline $9 / 2$ & 7,000 & 1.2100 & - & $8,470.00$ & - & - \\
\hline $10 / 1$ & 7,000 & 1.1000 & - & $7,700.00$ & - & - \\
\hline $11 / 0$ & 7,000 & 1 & - & $7,000.00$ & - & $95,056.34$ \\
\hline Total & 35,000 & - & - & $95,056.34$ & $-25,520.66$ & - \\
\hline
\end{tabular}

So, MIRR represents the internal payback rate of a project, the cash flow of which is modified in such a way that all negative net cash flows are transferred to project start, and net positive cash flows - to the finish. At the same time, the MIRR calculation formula is based on the ratio of benefits to costs:

$$
M I R R=\sqrt[\tau]{\frac{\sum_{n^{\prime}=0}^{\tau}\left(P_{n^{\prime}} \cdot K_{n^{\prime}}\right)}{\sum_{n^{\prime}=0}^{\tau}\left(C_{n} \cdot k_{n}\right)}}-1,
$$

where $P_{n}$ - net cash inflows (benefits) in the period $n^{\prime}$; $C_{n}$ - net cash outflows (expenses) in period $n ; K_{n^{\prime}}-$ compounding coefficient; $k_{n}$ - discounting coefficient.

According to the business case (Table 5), if the initial rate, for example, is $10 \%$, the MIRR is:

$$
M I R R=\sqrt[11]{\frac{95056.34}{25520.66}}-1=0.126982562 \text { or } 12.70 \% .
$$

Let's also note that the IRR of cash flow, which consists of two corresponding amounts and is shown in column 7 of the Table 5 , is exactly $12.70 \%$. For comparison, let's show that in the case $i=12 \%$, the MIRR (based on the data given in column 2 of Table 5 ) is $13.74 \%$. So, in the appropriate context, the higher the risk-adjusted rate of bringing cash flows to the start and finish of the project, the higher the MIRR becomes. Thus, despite the fact that MIRR takes into account all four factors of determining the value, this indicator is not acceptable for use as a criterion for the project value dynamics.

Based on the above, summing up the first stage of the selection, it should be said that only two of the five 
applicants remained for the role of the corresponding criterion (in assessing the financial results of the work of the value engineering team $-\mathrm{NPV}$ and BCR. To implement the second stage of choosing the best alternative, let's simply increase the scale of the project (Table 6), which serves as a model for analyzing the properties of the relevant criteria.

Forecast of cash flows with a doubling of the scale

Table 6 of the project, thousand USD

\begin{tabular}{|c|c|c|c|c|}
\hline Year & $\begin{array}{c}\text { Capital } \\
\text { investments }\end{array}$ & $\begin{array}{c}\text { Revenues during } \\
\text { operating activities }\end{array}$ & $\begin{array}{c}\text { Expenses during } \\
\text { operating activities }\end{array}$ & $\begin{array}{c}\text { Net cash } \\
\text { flow }\end{array}$ \\
\hline 0 & $-16,000$ & - & - & $-16,000$ \\
\hline 1 & $-24,000$ & - & - & $-24,000$ \\
\hline 2 & $-16,000$ & - & - & $-16,000$ \\
\hline 3 & - & 32,000 & $-18,000$ & 14,000 \\
\hline 8 & - & 32,000 & $-18,000$ & 14,000 \\
\hline 9 & - & 32,000 & $-18,000$ & 14,000 \\
\hline 10 & - & 32,000 & $-18,000$ & 14,000 \\
\hline 11 & - & 32,000 & $-18,000$ & 14,000 \\
\hline Total & $-56,000$ & 288,000 & $-162,000$ & 70,000 \\
\hline
\end{tabular}

Using the above approach, discounted cash flows are calculated, provided, for example, if $i=12 \%$ (Table 7 ).

Table 7

Present value of cash flows for the project with a double increase in its scale)

\begin{tabular}{|c|c|c|c|c|}
\hline $\begin{array}{c}\text { Year, } \\
n\end{array}$ & $\begin{array}{c}k_{n} \text { in the case } \\
\text { of } i=12 \%\end{array}$ & $\begin{array}{c}\text { Discounted net } \\
\text { cash flows, } \\
\text { thousand U5D }\end{array}$ & $\begin{array}{c}\text { Discounted } \\
\text { benefits, } \\
\text { thousand USD }\end{array}$ & $\begin{array}{c}\text { Discounted } \\
\text { costs, } \\
\text { thousand U5D }\end{array}$ \\
\hline 0 & 1 & $-16,000.00$ & 0.00 & $16,000.00$ \\
\hline 1 & 0.8929 & $-21,428.57$ & 0.00 & $21,428.57$ \\
\hline 2 & 0.7972 & $-12,755.10$ & 0.00 & $12,755.10$ \\
\hline 3 & 0.7118 & $9,964.92$ & $22,776.97$ & $12,812.04$ \\
\hline 8 & 0.4039 & $5,654.37$ & $12,924.26$ & $7,269.90$ \\
\hline 9 & 0.3606 & $5,048.54$ & $11,539.52$ & $6,490.98$ \\
\hline 10 & 0.3220 & $4,507.63$ & $10,303.14$ & $5,795.52$ \\
\hline 11 & 0.2875 & $4,024.67$ & $9,199.24$ & $5,174.57$ \\
\hline Total & - & $9,283.40$ & $135,924.74$ & $126,641.34$ \\
\hline
\end{tabular}

So, the NPV of the project now is 9,283.40 thousand USD, doubled (for comparison, see Table 2). However, the project $\mathrm{BCR}$ remained unchanged:

$$
B C R=\frac{135924.74}{126641.34}=1.0733 .
$$

Let's ask a simple question: did the engineering qualitative changes in the project take place, or was there some kind of innovation? Obviously not. Thus, it is proved that only BCR can act as a criterion for monitoring the dynamics of the project value (assessing the quality of the results of the work of the engineering team).

Thus, NPV is an indicator that very well serves the task of maximizing the wealth of investors. This indicator responds to both intensive and extensive factors of influence on the created value. Based on the fact that the World is an unlimited and inexhaustible source of wealth, NPV from many points of view could be completely satisfied. However, in the era of modern challenges (the requirement to achieve results not at the expense of nature, but in harmony with it, minimizing any negative impacts, taking care of future generations), BCR should become number one not only in the context of engineering. Meanwhile, let's note that the above analysis did not aim to determine all the disadvantages and advantages of individual indicators, but was carried out to select the best of them to control the dynamics of value.

6.3. Justification of isovalue graphs. The line of qualitative, dynamic equivalence/isovalue conditionally shows all possible options for combining (integral balance) of four project effectiveness factors, according to which the «benefit-cost» ratio (coefficient) is at the same constant level. A shift in the line of equivalence is possible under the influence of innovation, engineering. Increasing the project value in an extensive, static way (only because of the growth in the scale of the project) does not lead to a shift in the line of qualitative equivalence to a higher level (Fig. 1).

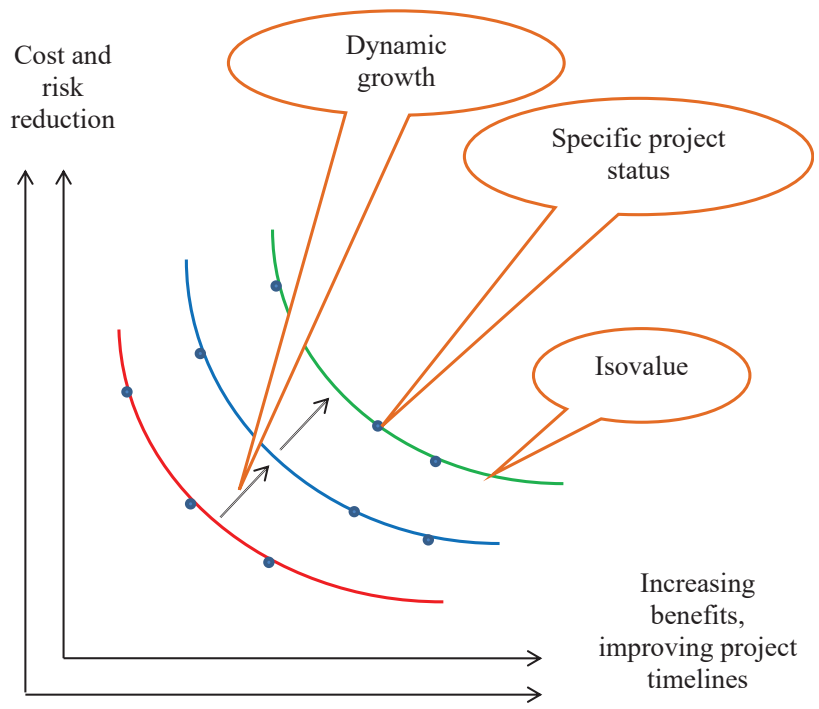

Fig. 1. The conditional image of the lines of project value equivalence (on the plane, but virtually in the four-dimensional space «time-benefit-cost-risk»)

The line of equivalence is a continuous function, not a collection of discrete points. For any given level of BCR, a line of equivalence can be drawn that shows various combinations of efficiency factors (benefits, costs, risk, and timing). Equivalence lines do not have growth segments the gain in some factors in the formation of efficiency is reflected in the corresponding deterioration of others.

In the theory of the project value dynamics, isovalue is the «geometric place of points» in the four-dimensional space of factors in which different combinations of benefits, costs, terms (chronology) and risk give the same economic-engineering level of value. One example of two different points lying on the same isovalue line is the situation shown above and is illustrated by formulas (5) and (8). This example refers to a mirror change in benefits and costs when the project scale has simply increased. 
Another example, it is advisable to give, concerns the mirror change of two other factors: timing and risk. This time let's plan to start part of the work as late as possible, but without violating the construction completion date (according to the schedule, at the moments of the «late start» of the works). As a result of such a decision, within the framework of the case, the timetable of investments in the project will change (Table 8).

Table 8

Cash flow forecast for the transfer of the dates of the start of part of the works, thousand USD

\begin{tabular}{|c|c|c|c|}
\hline Year & Capital investments & $\begin{array}{c}\text { Revenues during } \\
\text { operating activities }\end{array}$ & $\begin{array}{c}\text { Expenses during } \\
\text { operating activities }\end{array}$ \\
\hline 0 & $-16,000$ & - & - \\
\hline 1 & $-16,000$ & - & - \\
\hline 2 & $-24,000$ & - & - \\
\hline 3 & - & 32,000 & $-18,000$ \\
\hline 8 & - & 32,000 & $-18,000$ \\
\hline 9 & - & 32,000 & $-18,000$ \\
\hline 10 & - & 32,000 & $-18,000$ \\
\hline 11 & - & 32,000 & $-18,000$ \\
\hline Total & $-56,000$ & 288,000 & $-162,000$ \\
\hline
\end{tabular}

Consequently, the distribution of capital investments in years 1 and 2, relative to the previous scenario (Table 6), has changed. The remaining cash flow figures for the project remained unchanged. If this decision did not affect the risks, then the effectiveness of the project would increase accordingly. However, the risk of delaying the start date of receiving benefits from the project has grown in such a way that the risk-adjusted discount rate has become not $12.0000 \%$, but $12.3324 \%$. As a result, the discounted benefits and costs of the project turned out to be as indicated in the Table 9 .

Present value of project income and expenses (according to the updated scenario)

\begin{tabular}{|c|c|c|c|}
\hline $\begin{array}{c}\text { Year, } \\
n\end{array}$ & $\begin{array}{c}k_{n} \text { in the case of } \\
i=12.3324 \%\end{array}$ & $\begin{array}{c}\text { Discounted benefits, } \\
\text { thousand USD }\end{array}$ & $\begin{array}{c}\text { Discounted costs, } \\
\text { thousand USD }\end{array}$ \\
\hline 0 & 1 & 0.00 & $16,000.00$ \\
\hline 1 & 0.8902 & 0.00 & $14,243.44$ \\
\hline 2 & 0.7925 & 0.00 & $19,019.59$ \\
\hline 3 & 0.7055 & $22,575.37$ & $12,698.65$ \\
\hline 8 & 0.3944 & $12,621.46$ & $7,099.57$ \\
\hline 9 & 0.3511 & $11,235.82$ & $6,320.15$ \\
\hline 10 & 0.3126 & $10,002.29$ & $5,626.29$ \\
\hline 11 & 0.2783 & $8,904.19$ & $5,008.61$ \\
\hline Total & - & $133,431.13$ & $124,318.05$ \\
\hline
\end{tabular}

So, the project BCR again remained unchanged:

$$
B C R=\frac{133431.13}{124318.05}=1.0733 \text {. }
$$

Thus, this point in the space of «benefits-costs-timerisk» is on the same line of isovalue.
Properties of isovalues (which somewhat resemble the corresponding properties of isoquanta):

- lines of isovalues can't intersect;

- each subsequent line of isovalue, which runs farther from the origin, reflects a higher level of intense project value;

- lines of isovalues concave relative to the origin.

The above is the fundamental basis for building an investor control process for the effectiveness of the work of the engineering team of the construction project value.

Fig. 2 shows the action diagrams of SADT (Structured Analysis and Design Technique), which reflects the process of monitoring the project value (effectiveness) dynamics.

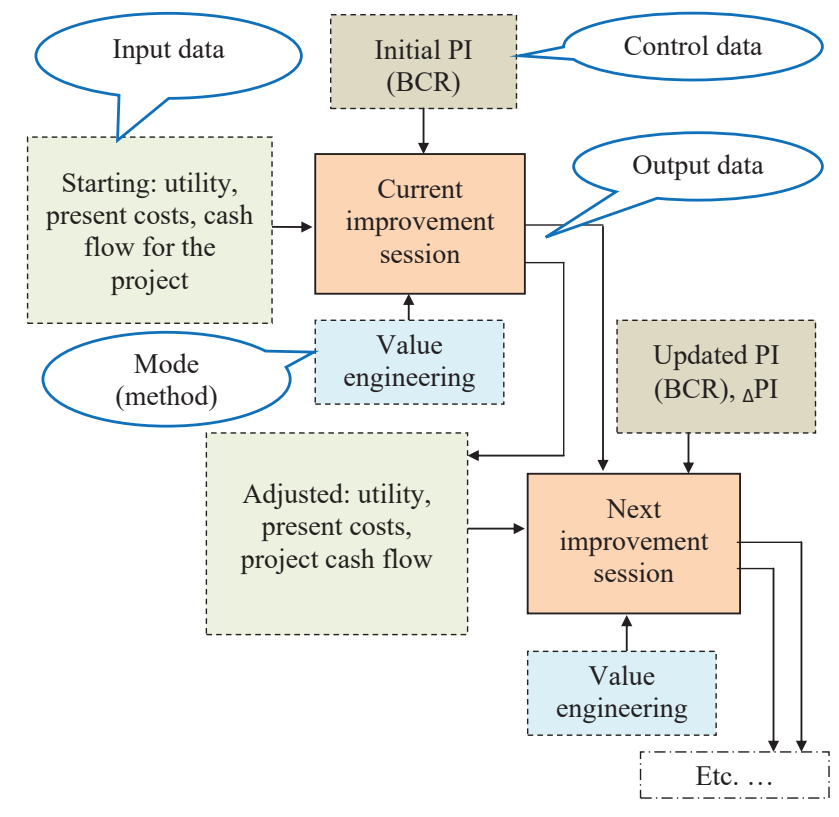

Fig. 2. SADT action diagram, which reflects the process of monitoring the project effectiveness (value) dynamics

The key task of controlling the dynamics of value is to check whether the intensive project efficiency for the investor (project initiator, customer, regional economy) has increased (and by how much has increased) according to the results of the passed session of the functional analysis (value engineering). At the same time, there is a significant and mandatory limitation: such an increase in project efficiency should not take place at the expense of environmental impacts (that is, without harming future generations). Another task of controlling the dynamics of value is to compare the increase in the economic efficiency of the project due to the last engineering session with the corresponding increase in the «benefit-cost» ratio (BCR) for previous cycles of value-functional analysis. The BCR for the first start-up engineering session is compared to one.

The proposed process for monitoring the project value dynamics is based on the recognition of the difference between dynamic and static development vectors; it has the following graphic explanation (Fig. 3). The initial project value $V_{1}$ in this diagram is determined by the conditions of four factors: risks $R_{1}$, timetable $T_{1}$, benefits $B_{1}$ and costs $C_{1}$. If the gain in one of these factors is offset by a mirror loss in others (changes will occur within the framework of one isovalue), and in addition, the scale of the project will not change, then its value will remain at the level of $V_{1}$. 
The financial and economic value, conceptually speaking, can change in the three ways indicated below.

Firstly, the value can increase by attracting additional resources and/or increasing the risks of the environmental impact of the project. Thus, the project value will increase «statically» from $V_{1}$ to $V_{2}$. The project will remain at the previous isovalue, but its scale will expand. This development vector in the graphic diagram is parallel to the abscissa axis (Fig. 3).

Secondly, value can grow thanks to purely innovation and without increasing the level of risk of the environmental impact of the project. On this development vector, value will increase «dynamically» from $V_{1}$ to $V_{3}$. The project will reach a higher isovalue, and its scale will not change. This development vector in the graphic image is parallel to the ordinate axis (Fig. 3). It is this path that is reflected in the BCR (PI) financial and economic indicator and is the mission of the value engineering teams. By the way, BCR is very similar to the definition of value, which is used in value-functional analysis [6] and hierarchical analysis. This, in particular, promotes mutual understanding and convergence in communications between project stakeholders (in the integrated Crystal model of value management [18].

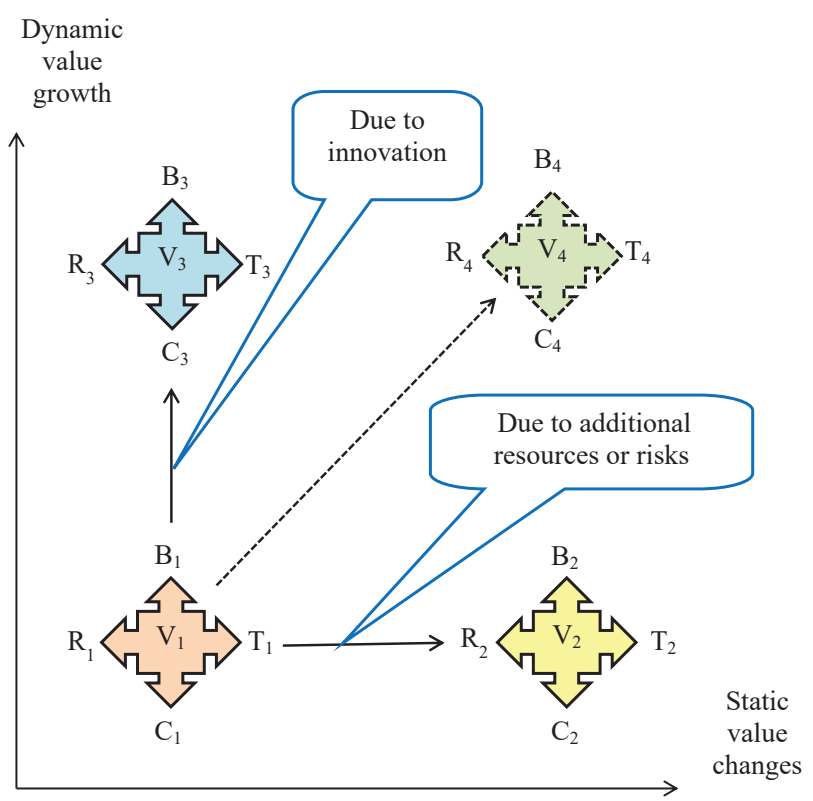

Fig. 3. Economic and engineering interpretation of the difference between dynamic and static growth of the project value, where: $C$ - costs; $B$ - benefits; $B$ - risks; $T$ - timetable; $V$ - value

Thirdly, the value of a project can increase both dynamically and statically. Thus, the project value will increase from $V_{1}$ to $V_{4}$ thanks to both innovation and scale-up. This development vector is indicated in Fig. 3 by dashed line. The indicated path is adequately recorded by the NPV indicator and serves to maximize the wealth of the project investors, however, especially in the face of modern challenges, it does not guarantee development «in harmony with nature».

\section{SWOT analysis of research results}

Strengths. The above presented Fig. 3 and related explanations clearly reveal the essence of the first value dynamics law. The second law confirms the advisability of the largest efforts in engineering value at the initial stage of the project, and the third - that each subsequent project has its own capabilities for innovative improvement of value. Thus, the proposed approach provides such a control process, contributes precisely to dynamic development, taking into account the changing potential of innovation during the project cycle and can be applied in any number of consecutive projects.

Weaknesses. At the same time, this approach has a fundamental limitation, namely, it does not allow determining the optimal project volume (the issue of the scope of the project is beyond the scope of this study).

Opportunities. Let's note that the BCR calculation based on annual cash expenditures and receipts, rather than net cash flows, distinguishes this criterion from other indicators. This feature of BCR further contributes to the fact that the process of controlling the dynamics of the project value meets the tasks of saving resources and protecting the environment.

Threats. Regarding the controversial issues of the study, it should be emphasized that despite global environmental challenges and climatic threats, financial and economic science, mainly, still considers NPV the most appropriate indicator for making investment decisions. Thus, the implementation of the proposed approach in some projects and companies may meet with resistance.

\section{Conclusions}

1. The first project value dynamics law emphasizes that a qualitative, dynamic growth of value occurs only through innovation or rationalization, and the rest of the project changes is static. Therefore, this law proves that exactly a dynamic, intensive increase in project efficiency should be considered as an effective, real result of value engineering, in the financial and economic context.

The second law of value dynamics indicates that entropy is gradually decreasing as a result of the project. Thus, the earlier engineering sessions take place (within the project life cycle) for introducing innovations, the higher the potential for influencing the dynamics of the project value.

The third project value dynamics law provides that the absolute maximum value cannot be achieved. So, innovation, unlike other factors of financial and economic growth, is an inexhaustible source of increasing the value of projects.

2. The change in the «benefit-cost» ratio (BCR) adequately reflects the project value dynamics. This indicator clearly takes into account all four factors of the project's effectiveness (time, benefits, costs, risks) and captures precisely dynamic, qualitative changes in value. In addition, $\mathrm{BCR}$ relies on all the benefits and costs (and not on their «balance») throughout the project life cycle, thereby helping to reduce the overall environmental load of the project.

By this time, it was traditionally believed that the net present value (NPV) is the method of evaluating investment projects, which best helps maximize wealth. However, this indicator takes into account not only dynamic, qualitative changes in the project value, but also purely quantitative, static ones. Thus, NPV is not aimed at compliance with priority restrictions on the use of resources and in modern conditions, at least in the context of engineering, is not the best.

3. Charts of isovalue demonstrate the potential states of the financial and economic project value in the fourdimensional space «time-benefits-costs-risks». If, according to the results of the engineering session, the project remained 
at the same isovalue, which means ${ }_{\triangle} B C R=0$, then there was no dynamic change in efficiency. The shifts that occurred were of a static nature, and there were no real innovations. If ${ }_{\triangle} B C R>0$ (the project moved to a higher isovalue), then there was a dynamic increase in value. The greater the $\triangle B C R$, the higher the project value dynamics and the more successful the innovations were. In this way, the investor controls the influence of engineering on the effectiveness of the project, subject to a business strategy in harmony with nature.

\section{References}

1. Koke, B., Moehler, R. C. (2019). Earned Green Value management for project management: A systematic review. Journal of Cleaner Production, 230, 180-197. doi: http://doi.org/10.1016/ j.jclepro.2019.05.079

2. The Royal Swedish Academy of Science. (2018). Economic Growth, Technological Change, and Climate Change. Available at: https://www.nobelprize.org/uploads/2018/10/advancedeconomicsciencesprize2018.pdf

3. Yongxiang, L. (2017). Evolution and Value of Design. Strategic Study of CAE, 19 (3), 1-6. doi: http://doi.org/10.15302/ j-sscae-2017.03.001

4. Martinsuo, M., Klakegg, O. J., van Marrewijk, A. (2019). Editorial: Delivering value in projects and project-based business International Journal of Project Management, 37 (5), 631-635. doi: http://doi.org/10.1016/j.ijproman.2019.01.011

5. Alfraidi, Y. N., Ibrahim, A. O. (2018). Value and quality in architecture: a study of the principles of value engineering. Journal of Al Azhar University Engineering Sector, 13 (47), 514-529. doi: http://doi.org/10.21608/auej.2018.19064

6. SAVE International (2007). Value Methodology Standard and Body of Knowoledge. Available at: http://www.pinnacleresults.com/ images/VE_Standard_from_SAVE.pdf

7. Bushueva, N. S. (2007). Systemnaia dynamyka na modely tsentrov vlyianyia v proektakh orhanyzatsyonnoho razvytyia. Uprazlinnia proektamy ta rozvytok vyrobnytstva, 1 (21), 29-33. Available at: https://cyberleninka.ru/article/n/sistemnaya-dinamika-upravleniya-programmami-organizatsionnogo-razvitiya/viewer

8. Schumpeter, J. (1934). Theory of Economic Development: An Inquiry into Profits, Capital, Credit, Interest, and the Business Cycle. Cambridge: Harvard University Press, 255. doi: http:// doi.org/10.4324/9781315135564

9. Schumpeter, J. (1939). Business Cycles: A Theoretical, Historical and Statistical Analysis of the Capitalist Process. New York: MacGraw Hill, 448. doi: http://doi.org/10.1522/030021081
10. Bazhal, I. (2017). The Political Economy of Innovation Development. Breaking the Vicious Cycle of Economic Theory. Springer International Publishing AG. doi: http://doi.org/10.1007/9783-319-54852-4

11. Vokoun, M. (2016). The Economics and Politics of Process Innovation and the Sustainable Urban Development. Procedia Engineering, 161, 2229-2233. doi: http://doi.org/10.1016/ j.proeng.2016.08.820

12. Abdu, M., Jibir, A. (2018). Determinants of firms innovation in Nigeria. Kasetsart Journal of Social Sciences, 39 (3), 448-456. doi: http://doi.org/10.1016/j.kjss.2017.07.006

13. Pivoriené, A. (2017). Real Options and Discounted Cash Flow Analysis to Assess Strategic Investment Projects. Economics and Business, 30 (1), 91-101. doi: http://doi.org/10.1515/ eb-2017-0008

14. Cruz Rambaud, S., Sánchez Pérez, A. M. (2017). The option to expand a project: its assessment with the binomial options pricing model. Operations Research Perspectives, 4, 12-20. doi: http:// doi.org/10.1016/j.orp.2017.01.001

15. Vesic-Vasovic, J., Radojicic, M., Nesic, Z., Mihailovic, D. (2014) Possibility of choosing development investment programs of a production company by applying discounted investment appraisal technique. Journal of Engineering Management and Competitiveness, 4 (1), 41-46. doi: http://doi.org/10.5937/ jemc1401041v

16. Ilg, P. (2019). How to foster green product innovation in an inert sector. Journal of Innovation $\mathcal{E}$ Knowledge, 4 (2), 129-138. doi: http://doi.org/10.1016/j.jik.2017.12.009

17. Pandit, D., Dr. S. M. Yadav, D. S. M. Y. (2012). Effective Project Controls at Project Development Stage. International Journal of Scientific Research, 2 (7), 137-139. doi: http:// doi.org/10.15373/22778179/july2013/47

18. Bugrov, O., Bugrova, O. (2017). Formation of a cumulative model for managing the value of construction projects. EasternEuropean Journal of Enterprise Technologies, 5 (3 (89)), 14-22. doi: http://doi.org/10.15587/1729-4061.2017.110112

Bugrov Olexander, PhD, Associate Professor, Department of Project Management, Kyiv National University of Construction and Architecture, Ukraine, e-mail: bugrov.oleksandr@gmail.com, ORCID: http:// orcid.org/0000-0002-2325-1545

Bugrova Olena, PhD, Associate Professor, Department of Economic Theory, National University of «Kyiv-Mohyla Academy», Ukraine, e-mail: bugrova.olena@gmail.com, ORCID: http://orcid.org/ 0000-0001-8447-282X 